\title{
The comparative agendas project in Latin America: data and coding
}

\author{
Shaun Bevan 1 \\ Anna M. Palau 2 \\ 1 Unviversity of Edinburgh, Edinburgh - United Kingdom \\ 2 University of Barcelona, Barcelona - Spain
}

This paper introduces the Comparative Agendas Project system of coding as well as a wealth of gathered and in process data from Latin America using this established and reliable system for capturing policy attention comparatively and over time. While this is not the first introduction of the coding system, it is the first introduction aimed at Latin America and a new type of political system beyond North American and European democracies. First, we present an overview of the Comparative Agendas Project (CAP) and the Master Codebook used to create comparative policy attention data across countries, over time, and between agendas. These details of CAP are discussed for Latin America in general and for Brazil, Colombia and Ecuador, countries that recently started to gather data using these coding.

Keywords: CAP; comparative analyses; Latin America; coding; master codebook.

\section{Comparative Agendas Project na América Latina: dados e codificação}

Esse artigo apresenta o sistema de codificação do Comparative Agendas Project, que é capaz de capturar a atenção política de maneira comparada e ao longo do tempo. Apresenta também uma ampla gama de dados coletados e em processamento na América Latina, já usando esse consolidado e confiável sistema de codificação. Embora não seja um sistema inédito, essa é a primeira vez que está sendo introduzido na América Latina e em um tipo de sistema político diferente do que se observa nas democracias da América do Norte e da Europa. Para isso, oferecemos um panorama do Comparative Agendas Project e de seu livro de códigos (Master Codebook), usado para obter dados de atenção política de forma comparada entre os países e suas agendas, ao longo do tempo. Esses detalhes são discutidos em relação a América Latina em geral e ao contexto nacional do Brasil, Colômbia e Equador, países da região que contam com a primeira leva de dados processados com esse sistema de codificação.

Palavras-chave: CAP; análise comparativa; América Latina; codificação; livro de códigos; master codebook.

\section{Comparative Agendas Project en América Latina: datos y codificación}

Este artículo presenta el sistema de codificación del Comparative Agendas Project, que es capaz de capturar la atención política de manera comparada y a lo largo del tiempo. Presenta también una amplia gama de datos recogidos y procesados en América Latina, sobre la base de este consolidado y fiable sistema de codificación. Aunque no sea un sistema inédito, esta es la primera vez que se introduce en América Latina y en un tipo de sistema político diferente del que se observa en las democracias de América do Norte y Europa. Para ello, ofrecemos una descripción del Comparative Agendas Project y de su libro de códigos (Master Codebook), usado para obtener datos de atención política de forma comparada entre países y distintos tipos de agendas a lo largo del tiempo. Esos detalles se discuten en relación con América Latina en general y con el contexto nacional de Brasil, Colombia y Ecuador, países de la región que cuentan con el primer conjunto de datos recogidos con ese sistema de codificación.

Palabras clave: CAP; análisis comparativo; América Latina; codificación; libro de códigos; master codebook. 


\section{ACKNOWLEDGEMENT}

This work was supported by the research project 'La oposición política en España: estrategias en la arena parlamentaria' (RTI2018-096950-A-I00).

\section{INTRODUCTION}

How to code policy issues such as education, law and order, and housing can be done in many different ways with separate and unique understandings of the world. Grouping data based on patterns extends to both human and computer coding techniques. While advances continue to be made in computational methods, these techniques are not particularly contusive to long time series or comparative analyses. Human coding presents its own issues. As it turns out most policy areas including culture, fishing, and even terrorism are often very different from the point of policy and policymakers dependent on context. The Comparative Agendas Project (CAP; Retrieved from https:// www.comparativeagendas.net/) is a community of researchers that have worked to tackle the difficulties of classifying policy over time and cross-nationally.

This article introduces three of the newest projects in the CAP from Latin American: Brazil, Colombia, and Ecuador. Countries in the region are characterized by incredible diversity, especially at a cultural level, but share common traits and unsolved problems such as corruption, political turmoil, and the instability of institutions. The ability to measure the policy process and the priorities of political actors with precision using CAP data, will allow for the exploration of agenda-setting dynamics across Latin American countries from a totally new perspective, addressing questions that have so far been subjected to little empirical investigation. This will not only open a new research agenda in the region but also provide opportunities for comparative research more broadly. The paper covers their politics, some unique issues, and some of the research within countries and comparatively that could be conducted with this new, and public collection of data.

The remainder of this paper is as follows. First, we discuss how the CAP was formed and its direction in coding policy attention and not targets of policy. Second, we explain how the Master Codebook was created and why. Next, we explain the characteristics of the recent data created by projects in Brazil, Colombia and Ecuador, explaining country peculiarities and offering potential research agendas. Finally, we conclude with some general reflections on the CAP, applying the CAP to Latin America, and the potential for comparative research beyond the region.

\section{ESTABLISHING A POLICY FOR CODING COMPARATIVELY}

The roots of the CAP stem from the US Policy Agendas Project (US PAP). A well-established project created by Frank Baumgartner and Bryan Jones, the US PAP has been widely used by practitioners and academics alike. Focused on creating a number of datasets covering the policy content of political agendas using a common coding system the project started with US Congressional Hearings. Using a series of major and subtopic codes the work resulted in a detailed and comprehensive codebook covering all the policies addressed by the US Federal Government (see Jones \& Baumgartner, 2005). 
RAP | The comparative agendas project in Latin America: data and coding

The names of the CAP Master Codebook's major topic codes are in Box 1. The CAP website maintains an up to date codebook complete with subtopics and general annotations at www. comparativeagendas.net.

\section{BOX 1 CAP MASTER CODEBOOK MAJOR TOPIC CODES}

\begin{tabular}{|c|c|}
\hline Major Topic & Title \\
\hline 1 & Domestic Macroeconomic Issues \\
\hline 2 & Civil Rights, Minority Issues, and Civil Liberties \\
\hline 3 & Health \\
\hline 4 & Agriculture \\
\hline 5 & Labor and Employment \\
\hline 6 & Education \\
\hline 7 & Environment \\
\hline 8 & Energy \\
\hline 9 & Immigration and Refugee Issues \\
\hline 10 & Transportation \\
\hline 12 & Law, Crime, and Family Issues \\
\hline 13 & Social Welfare \\
\hline 14 & Community Development and Housing Issues \\
\hline 15 & Banking, Finance, and Domestic Commerce \\
\hline 16 & Defense \\
\hline 17 & Space, Science, Technology, and Communications \\
\hline 18 & Foreign Trade \\
\hline 19 & International Affairs and Foreign Aid \\
\hline 20 & Government Operations \\
\hline 21 & Public Lands, Water Management, and Territorial Issues \\
\hline 23 & Cultural Policy Issues \\
\hline
\end{tabular}

Source: Elaborated by the authors. 
Over time and even before the creation of the CAP the US PAP codebook had been revised. Most notably the folding of family issues into law, order and family issues ${ }^{1}$. The codebook had further been revised to fit new types of data. For example, media data based on random samples of newspaper articles contained reports on sports scores, death notices and other items not related to policy. In this case new, non-policy codes were created to accurately represent all the sampled data.

All these revisions like the revisions to create the CAP Master Codebook follow what Bryan Jones calls "prime directive," of the CAP. This fundamental rule states that existing codes may never be combined, but that new codes can be created either to match truly new concerns or through the further separation of existing codes. For example, weather reports, required a new and non-policy focused code for the creation of the US media. Outside the US the existing subtopic of immigration proved to be more fundamental in European projects where the policy was and has remained a fundamental topic for the EU (see Guiraudon, 2000).

\subsection{Defining CAP data}

So far the CAP has been initiated in Australia, Belgium, Canada, Croatia, Denmark, France, Germany, Hungary, Israel, Italy, the Netherlands, New Zeland, Portugal, China, Russia, South Korea, Spain, Switzerland, Turkey, United Kingdom, United States, the US States of Florida and Pennsylvania, and the European Union. With enlargement to Latin American, the project will incorporate Brazil, Colombia and Ecuador in a first wave. CAP data includes a wide range of datasets using or able to be recoded to the CAP Master Codebook in order to consistently and systematically identify the policy attention of policy focused data based on a content analysis of spoken or written words. Policy attention is the substantive focus of each item in the database. Observations can and do vary from legislative questions and proposed bills to more aggregated measures such as 'most important problem' type questions aimed at capturing the policy priorities of the public. (e.g. Bevan \& Jennings, 2014). All data follows a common set of rules in order to accurately code the policy focus of each observation. The majority of CAP datasets exist over a long time frame and include the entire population of observations within that time period. Every dataset includes as much information as practically possible including the item to be coded and identifying information such as titles or links to complete documents. While practically copyright or other legal concerns can limit how open data can be, the ideal of completely open and transparent data is always strived for.

\subsection{Specific and limited coding}

CAP coding is both specific and limited to policy content. While the goal of CAP data is the comprehensive coding of large, over time datasets, its focus is on policy attention. Many different fields and subfields make up the backgrounds of the scholars in the CAP community, from political

\footnotetext{
${ }^{1}$ The folding of codes is the reason for the missing major topic number 11 in the CAP codebook. Originally family issues, topic 11 was folded into law and order based on how government approaches family issues such as marriage or custody of children as legal matters.
} 
scientists, to legal and media scholars as well as several areas in sociology. What ties all these scholars together is an interest in political attention. This very general focus rather than a focus based on political parties, or how the media engages with politics, or the societal concerns around issues led to the need for a robust, but limited coding system. Attention is however the sine qua non of policy-making that can lead to policy moving in a particular direction, based on a way of stating the issue (framing) and due to partisan or other specific preferences. Focusing only on attention, CAP coded data may not fit many political questions. However, the clear and consistent guidelines used, the transparency of the data, with most datasets offering the raw text or information used to code each observation, means that adding preference or other concepts on top of CAP data is generally quite straightforward and something to be strongly encouraged. While not all datasets can offer raw data due to practical or legal reasons, when it is available users can easily use CAP data both as a resource for attention, and as a database of policy with whatever additional coding frames they want on top of it.

\subsection{Code the policy and not the target for policy}

A policy is not the same as its target. For example, the global financial crisis was a target for many different policies across the world. These policies focused on employment, regulation of financial industries, consumer confidence, etc. In fact, in many countries, austerity meant that nearly every policy area was affected through budgeting. The solutions, right or wrong, to the crisis were not just about the direct crisis, but about how all policy could or should function during a period of economic woe. Solutions for this target, the problem of the financial crisis, included cuts to spending, tax reform, social welfare changes, and support for new jobs and businesses. The crisis was a shock that drove changes in most policy areas government dealt with and continues to have affects to present day.

This choice to focus on the substance of policy is one of the most common criticisms of the CAP (e.g. Dowding, Hindmoor, \& Martin, 2016). However, this is a criticism of approach or focus and not quality. Clearly in order to fully understand government response to a large problem the CAP coding alone is not enough. Take another target for policy, terrorism for example. Terrorism can be addressed by different actors such as the police, the military, or more global institutions. The threat of terrorism can also be addressed through different means such as surveillance, additional security checks at ports of entry, or the monitoring of suspicious financial activity. Like with the financial crisis the target of terrorism can and is addressed through many policy areas.

For those researchers interested in the policies aimed at addressing targets additional coding, of the target or targets for policy are necessary. This can be accomplished by searching or adding new code frames to the raw CAP data and is certainly a worthy focus for research. What the targets for policy are though, is much less predictable, changes over time and can be more unique for each country. 


\section{THE CAP MASTER CODEBOOK}

A codebook that encompasses all policy government deals with from 100 years ago to today, from North American to Eastern Europe and increasingly from democracies to non-democracies is the most significant accomplishment of the CAP Master Codebook. However, it is also a compromise, a selection of 21 major topics and over 200 subtopics that loses the detail of major events like German reunification, uncommon political systems like constitutional monarchies, and disputed territories as some examples. Individual projects are however free to create project specific codebook alternations to address these and other unique policy areas and contexts. That is, so long as the compromise of the CAP Master Codebook can always be matched back to.

That said a clear way to match data was not always the norm. Seemingly every year a new project or several join the CAP. Until the creation of the Master Codebook in 2014 these projects brought their own changes to the codebook from minor reinterpretations of existing codes to the creation of new codes without regard to comparative analyses. The lack of a strong hierarchical leadership or a central source of funding has been a strength for the wealth of coverage of CAP data and perhaps surprisingly has and continues to work well. Coordination is key though and coding needed a level of coordination and control that did not fit this diffuse leadership arrangement. As a result, a good deal of drift in the meanings, coverage, and application of codes created a real problem, especially on the subtopic level. While the majority of the changes were necessary within projects to address their unique context, many different solutions for shared problems or misunderstandings had been created and some policies were considered wholly unique even if conceptually they fit within existing codes, at least for the purpose of comparison. Internally every project does an excellent job of both coding and reconciliation with high coding agreements often close to $90 \%$ with additional cleaning bringing the quality of the final data even higher. It is easy to forget that the process of agreement also needs to be addressed across projects though.

Generally comparable findings existed before the creation of the Master Codebook such as the effect of core issues on government attention (e.g. Jennings et al., 2011) and a law of patterns in public policy (e.g. Jones et al., 2009). However, these analyses were limited with a number of cross-national codebook incompatibilities preventing certain comparisons. Some were obvious, such as how immigration was treated either as its own policy, a civil rights based policy, or a labor force based policy and these could be addressed by localized recoding. Other differences did not appear severe enough to undermine aggregate level work with robustness checks like jack-knifing of major topics and countries in comparative work generally no affecting substantive findings (e.g. Jennings et al., 2011). Before the completion of the Master Codebook researchers faced more than 450 at least partially unique subtopics across more than a dozen projects from the initial number of 225 subtopics. While most of the additional subtopics are minor alternations, without a clear tool indicating how they matched work beyond the major topic level was difficult to say the least.

The early development of the CAP Master Codebook involved a wide number of people from the community with Jeroen Joly and Herschel F Thomas III having laid the groundwork through a comprehensive comparison of codebooks, but only a limited discussion of how this coding was 
completed in practice had occurred. This initial crosswalk was used for a number of the early comparative papers from the CAP (e.g. Baumgartner, Brouard, Green-Pedersen, Jones, \& Walgrave, 2011) predominately focused on major topics. This left a good deal of work to be done with subtopics and how codes were applied in practice leaving many open and persistent questions. The history and logic behind the creation of the CAP Master Codebook are laid out in detail in the rest of this section. This is both so that researchers can understand its limitations, but also how the CAP can claim to have a consistent coding system between countries, over time and across policy areas.

\subsection{Building the master codebook}

The process of creating a master codebook started early on with regular discussion in the now annual CAP conferences since the first European country projects received funding. This work started in earnest in the summer of 2012 and was led by Shaun Bevan with the backing and support of the project PIs. To start the process a set of simple, but clear objectives were set out in a memo explaining the process that was then opened to comments and discussion. These objectives were as follows: (1) Create a common Master Codebook that allows for accurate comparisons across all CAP datasets; (2) Minimize the overall amount of work by seeking a common middle ground between projects rather than asking any project to use a particular country's codebook; (3) Whenever possible avoid the need for recoding with appropriate aggregations.

The first objective was essential to keep the CAP both broad and inclusive of all comparative contexts captured by the projects. The second objective was to create a new Master Codebook, in other words to not impose an existing project's codebook on other projects. Beyond general goodwill, this was a practical decision as the middle ground, or the common elements of the codebooks from each project was the best point for comparison. The third and final objective was the most practical with many projects lacking additional or having never had funding the amount of work each project had to do needed to be realistic. The goal was also one of comparison of existing work, not the creation or new codes or new work. Overall the objectives led to a least common denominator Master Codebook that could maintain a high level of detail while splitting work between projects to create a coding of policy attention that cut across both existing and potential future projects.

To start the work each project was asked to create an English language codebook to facilitate in person meetings between project PIs, coders, and managers, and Shaun Bevan. These codebooks were checked against other codebooks and a draft master codebook to identify possible differences in how codes were being applied. Teams also completed a common coding exercise based on UK Acts of Parliament with a high number of difficult or borderline cases intended to highlight how each project approached the most likely problem areas. Meetings were then held discussing the coding exercises, the comparison between English language codebooks and the draft master codebook, and any other issues or concerns that teams had. These meetings normally took one to one and half working days. Some issues were immediately addressed, others were discussed in further meetings with other projects, and a few were solved later in the process. Following these meeting Dr. Bevan created a revised Master Codebook with 21 major topics and 213 subtopics. 
With this new master codebook and a large number of small, but important inconsistences addressed through the face to face meetings a further memo explain the key differences between the Master Codebook and a number of project codebooks was sent to all teams. A discussion was then held at the 2013 CAP conference in Belgium where the revisions were explained and questioned in detail. Based on this and the revised codebook crosswalks between existing projects and the Master Codebook were created by Dr. Bevan and sent to teams for further comments. With any necessary changes made these teams then used the crosswalks to rework their data to fit the Master Codebook. While the number of major and subtopics remained unchanged over the course of this process, significant revisions to the names of each major and subtopic were made for them to be as general/ comparative as possible.

\subsection{Details, details, details... mean everything}

While intense, the process for creating the Master Codebook was quite straightforward based on the above, but also far from easy. The effort of creating something truly comparative between projects involved a tremendous amount of detail. In part this was contextual. Fisheries, a mainstay of agriculture or aquiculture in many seafaring nations like Denmark was an afterthought in countries as vast as the United States, and virtually a non-issue in landlocked nations such as Switzerland. That fisheries were their own unique policy area seemed to be fundamental in one case, overly complex or detailed in another, and not even a potential thought in some. In short, how much and how comprehensively policies are addressed differs by context both cross-nationally and over time. Addressing these contexts is what led to more than 450 subtopics across projects before the creation of the Master Codebook, a doubling of the original number included in the US Policy Agendas Project. Most of these subtopics were only slight revisions intended to capture minor, but important differences within projects. However, some were more unique such as the role of religion in government in some nations or the splitting of civil rights codes to pick up on additional nuances. Like fishing, culture had no real analog in the original US codebook and served as a constant source for debate across projects.

As the number of projects grew two of these revisions clearly emerged as a main or major policy area. The first, immigration was always at least a subtopic with many countries focusing on civil rights or labor concerns over immigration. The large number of EU projects in the CAP recognized immigration as a primary issue, one that had a significant role in the EU's creation (Guiraudon, 2000) and continues to affect contemporary politics.

The second, culture including its preservation and the promotion and continuation of native languages varies a great deal. Concerns over outside cultural influences from movies and TV as well as the prevalence of English in many different outlines led nations like Italy and France to produce large volumes of cultural policy. Many nations not only promote their own culture through funding, but also choose to dub over foreign language films and TV shows. While the US and UK who both have major roles to play in global media production produce very little to no cultural policy depending on the outline, cultural policy is clearly important comparatively. The fact that the US has so little cultural policy actually adds a great deal to the external validity 
of the project given the US has little concern or need to protect English or US culture from outside influence. Both culture and immigration were added to the master codebook as major topics reflecting the fact that on the whole they are primary policy areas for the majority of projects in the CAP.

The Master codebook addresses minor, but numerous issues of comparison by ensuring each project captures and codes policy in the same manner. This is done through a complete crosswalk between project codebooks and the Master Codebook. The use of a common and well-established was of coding allows for the CAP to be internally valid across projects as well as within projects over time and from dataset to dataset. In the next section, we introduce the databases developed so far by the new projects involved in the CAP from Latin America.

\subsubsection{Latin American Databases}

The Comparative Agendas Project has been developed in three Latin American Countries: Brazil, Colombia, and Ecuador. So far, these countries have created the databases summarized in Box 2. The main goal of these databases is to gather information that allows for the exploration of the impact of institutional factors, policy preferences and external events on agenda dynamics in these three countries. To do so, the three countries have collected and coded data on Presidential speeches, the legislative agenda, and the media agenda. We next explain the main characteristics and content of these databases and provide information on the research teams responsible for the collection and coding of data.

\begin{tabular}{|c|c|c|}
\hline & Dataset & Period \\
\hline \multirow[t]{8}{*}{ Brazil } & Public Opinion (Most Important Problem series) & 1996-2018 \\
\hline & Constitutional Amendments & $1992-2017$ \\
\hline & Legislative Decrees & \\
\hline & Laws and Complementary Laws & 2003-2014 \\
\hline & Provisional Measures & \\
\hline & Executive Orders & \\
\hline & Messages to the National Congress & \\
\hline & Investiture Speeches & 2003-2016 \\
\hline
\end{tabular}


RAP | The comparative agendas project in Latin America: data and coding

\begin{tabular}{|c|c|c|}
\hline & Dataset & Period \\
\hline \multirow[t]{6}{*}{ Colombia } & Bills & \\
\hline & & 1994-2018 \\
\hline & Bills to modify the constitution & \\
\hline & CONPES & \\
\hline & Media (Revista Semana) (work in progress) & \\
\hline & Laws & $1992-2019$ \\
\hline \multirow[t]{3}{*}{ Ecuador } & Presidential Speeches & $2007-2019$ \\
\hline & Organic Laws & 2009-2019 \\
\hline & Media (El telégrafo and El Comercio) & 2014-2019 \\
\hline
\end{tabular}

Source: Elaborated by the authors.

The concentration of power in the executive branch, and specifically the Presidency, characterizes Latin American countries. The hyperpresidentialism resulting from concentration of power in the hands of the President is far from the role the US president or any other president from any European country might have in the political system. In the three countries, the president is chosen by popular election, by absolute majority and if no candidate receives one, a second round election is held between the two top candidates. However, the power of the president is more restricted in Colombia, where the presidency is limited to a single term. Ecuador and Brazil limit the presidency to two consecutive terms, in the case of Ecuador following a controversial constitutional reform. In 2015 Correa forced the legislature to pass a measure which allowed unlimited presidential reelections; however, on 4 February 2018, in a nationwide referendum called by Moreno, Ecuadoreans voted by a landslide to limit presidents to two terms (Tartakoff, 2019, p. 15). In order to analyze the presidential agenda, the three countries have created databases on presidential speeches. Brazil have collected information about Presidential Speeches for the period 2003-2016, covering the Speeches of Lula da Silva (2003-2011) and Dilma Rousseff (2011-2016). The data relies on the Mensagens ao Congresso Nacional where the President expresses the policy priorities for the next year. The Ecuadorian team has collected information about Presidential Speeches covering the period 2007-2019, which include the Presidencies of Rafael Correa and Lenín Moreno. Colombia has not coded Presidential speeches as of August 2019.

The three countries have also collected information about the substantive agenda of the executive and the parliament. Two countries have bicameral legislatures (Colombian and Brazil), Ecuador unicameral elected through proportional representation. In Latin America, legislatures are inherently weak, not being independent but institutions subservient to the president and, along the executive, a part of the same organic integrated system (see Kline, Wade, \& Wiarda, 2018). 
They do not have the right to initiate or veto laws but (Ecuador's Congress can) work more as institutions that give advice and consent presidential acts. In Brazil however, the Congress has comparatively more power and independence that in Ecuador and Colombia. This allowed, for example, the Congress to remove Dilma Rousseff from the presidency in 2016 using corruption allegations. So far, Brazil has collected information about Constitutional Amendments for the period 1992-2017, and about Laws, Complementary Laws, Legislative Decrees, Provisional Measures, Executive Orders and Messages to the National Congress for the period 2003-2014. In the case of Colombia, the 1991 constitution granted the congress more powers but the executive still predominates. Laws have been coded for the period 1992-2018, and Bills and Bills to modify the Constitution for the period 1994-2018. CONPES documents, which refer to public policy reports prepared by the National Economic and Social Policy Council, the highest national planning authority, which acts under the direction of the President, have been coded for the period 1994-2018. In Ecuador, they coded all Organic Laws passed during the Correa presidency and former presidency of Moreno.

Finally, the Brazil team have also coded public opinion (most important problem series) for the period 1996-2018, and the Colombia and Ecuador ones have developed comprehensive and far-reaching database of stories covered in the front pages of newspapers. In Ecuador, the media has been a target of president Correa low tolerance for dissent (Collins, 2008, p. 308). The President aggressively has used the Courts against media to intimidate critical views. Correa sued El Universo, one of the country's main newspapers after a journalist wrote a piece accusing Correa of responsibility for civilian deaths in a police rebellion in 2010. Although the president finally pardoned the accused, the court ruled in favor of the President sentencing the journalist to three years in prison and a financial penalty of US\$ 40 million. The Ecuadorian team has coded the front pages of El Telégrafo and El Comercio for the period 2014-2019. Colombia has started coding the Revista Semana, a weekly political magazine for the period 1994-2018 (work in progress).

\subsection{The Latin American Research Teams}

In Brazil, the data was originally collected by Ana Cláudia Niedhardt Capella and Felipe Gonçalves Brasil with the collaboration of undergraduate students from Sao Paulo State University (UNESP) and graduate studentes from Federal University of São Carlos (UFSCar). Sponsoring Institutions are Department of Public Administration - Sao Paulo State University (UNESP), Programa de pós-graduação em Ciencia Política - Federal University of São Carlos (UFSCar). Funding came from The National Council for Scientific and Technological Development (CNPq) and Sao Paulo Research Foundation (FAPESP) ${ }^{2}$. In Ecuador, Pablo Ruiz Aguirre, from the International University of Ecuador (UIDE) - Loja is responsible for the project and coded most of the data also with

${ }^{2}$ Grant number 471414/2014-0 - chamada MCTI/CNPQ/MEC/CAPES No 22/2014; Grant number 424398/2018-4 - chamada MCTIC/ CNPq No 28/2018; Grant number 2018/16289-3; Grant number 2018/11032-4; Grant number 2016/21653-0. 
the support of undergraduate students. Financial support was provided by the Loja University. Juan Guillermo Vieira Silva, from the Universidad Nacional de Colombia, leads and coded the Colombian data.

\section{LATIN AMERICAN COUNTRIES SPECIFICITIES}

All Latin American countries have experienced in the last decades a substantive process of modernization, democratization and integration to the global economy (Kline et al., 2018). However, the region is still characterized by great linguistic, ethnic, geographic, economic and political diversity. The characteristics of democracy, the economic and the political system, are still far away from those in the United States and Europe, which makes the analysis of these countries particularly interesting from an agenda setting perspective. Next, we briefly examine the main specificities and particularities of each country for the time period covered by each dataset created. The goal is not to provide an exhaustive list of what can be done with the data. Among the main contributions of the CAP community is that it has created empirical information that allow researchers to assess trends in agenda dynamics that can be used to answer a countless number of questions. What we are aiming for here is to emphasize relevant political events, such as changes in presidencies as well as structural problems (e.g. corruption and violence), social mobilization processes (from indigenous to feminist movements) with the capacity to influence agenda dynamics in these countries.

\subsection{Brazil}

Brazil is a good example of how a change in the Presidency might transform the political agenda in Latin American countries. President Lula da Silva from 2003 to 2011 significantly reduced poverty levels by implementing ambitious social welfare programs while at the same time improving the country's economy by reducing inflation and containing fiscal spending. His reformist agenda fits with the post-neoliberal development movement that in Brazil and other countries like Ecuador, promised to deepen democracy, redistribute wealth, combine social equality and economic growth in a "new $21^{\text {st }}$-century socialism" (North \& Clarck, 2018). Contrary to other political leaders in the region however, Lula and other Brazil presidents have resisted the temptation to extend their time in power by increasing term limits, as president Correa did in Ecuador. Following the Rousseff impeachment the presidency of Michel Temer, from 2016 to 2019, was characterized for increasing poverty levels and public discontent with controversial shocking political decisions such as removing all women from government. More recently, the arrival of Bolsonaro to the Presidency, a conservative extreme right retired military with strong connections with the evangelical church, will certainly transform policy priorities in the country. The datasets created by the Brazilian team will allow analyses and comparisons of issue attention among these different presidencies and at the same time help address important questions related to political representation such as to what extent these Presidents keep their promises or respond to public priorities. 
Brazil suffers from deep, permanent structural problems that might also influence agenda-setting dynamics. A problem that has for long characterized the country, having deep connections to political and economic instability is the topic of corruption. Brazil is a patronagebased political system rooted in systemic corruption. This situation of generalized corruption has deep roots but the multiparty political system, the need to build coalitions in order to pass legislation and the legal inefficiency has fueled political corruption at all levels of government. Lula himself, the most popular Brazil president in history, ended up involved in corruption scandals, being so successful moving his agenda through Congress because he was paying people off (Crandall, 2018, p. 129; Gonçalves \& Niedhardt, 2019). Her successor, Dilma Russeff, was subjected to an impeachment process being accused of "crimes of responsibility" due to her alleged use of an arcane set of fiscal maneuvers known as pedaladas ("fiscal peddling") to pay for social spending (Fogel, 2019, p. 154). The impeachment of Rusself, who was replaced by Michel Temer, reveled the self-serving nature of the Congress, as what their members tried to do was to draw attention from their own corruption investigations (Crandall, 2018).

What is new on the topic of corruption is a lower public tolerance as a result of consolidation of a middle class, which together with a group of prosecutors willing to apply the law and aggressive media outlets, promote anticorruption measures. Corruption has such a political impact in Brazil even influencing the outcome of last year's election after Judge Sérgio Moro sentenced Lula to nine and a half years in prison, prohibiting him from running in the 2018 elections, and leaving the field open for far-right leader Bolsorano to assume the presidency (Fogel, 2019). In this context, where the idea that corruption is not a systemic problem in Brazil, but one generated by the Worker' Party, a military rule was presented as being less corrupt than civilian rule, legitimating the idea that Bolsonaro could restore credibility to Brazilian politics (Fogel, 2019). Overall, in this context, while the broad public and political elites should agree that corruption is a "compulsory" issue (Adler \& Wilkerson, 2013), namely it should be eradicated, we still know little about the extent to which different Presidencies and legislatures have prioritize this issue in the political agenda over time compared to other also pressing issues.

Another structural problem in the country is violence. Contrary to other Latin American countries, even having experience military coups, Brazil is characterized for having avoided radical political and social ruptures. The country experienced a non-violent independence from Portugal but military coups occurred along the $20^{\text {th }}$ century, the most important one in 1964 leading the country to 21 years of military regime. Levels of repression during these years however did not reach the levels of other Latin American military regimes that swept through Latin America during this period. Still, violence is a widely extended social problem. Brazil is among the deadliest countries in the world, with violence steaming from a combination of income inequality, poverty, drug trade and the lack of an effective state presence (Crandall, 2018). Criminal organizations control Brazil's cities promoting drug trafficking, robberies, extortion and other crimes especially in favelas where the creation of militias fighting the drug gangs has increased violence to dramatic levels. The implementation of "Pacifying Police Units" (UPP's), improved the relationship between police and favela residents resulting in a decrease of homicides and 
robberies. The analysis of attention to violence from an empirical, agenda-setting perspective, will allow for the exploration of questions like, whether this is an issue owned by right oriented parties, as it has been traditionally the case in the USA and also in Europe, or by the contrary, the fact that it is such structural important problem means that it has been prioritized by all political actors with little variation over time.

Finally, the pressure to build a beautiful Rio for the 2014 world cup first and later the 2016 Olympics, illustrate the impact of external events on agenda dynamics as these brought for example the problem of favelas, historically ignored, to the political agenda by means of forced eradication. The need to finance multimillion-dollar stadiums and infrastructures for these events contributed, together with economic contraction and increasing public discontent, Lula successor, Dilma Rousseff to manage Brazil's economic downturn. The country also provides grounds for exploring the role of civil society as agenda setting actors. The Landless movement (Movimento Sem Terra [MST]) is considered one of the most influential social movements in Latin America (McNee, 2005). Founded in 1984, it fights for radical agrarian reform, namely, state intervention to reverse historic land concentration trends, to promote a more just society. Lula was accused of being irresponsible to show public support for the movement, and it was among the most disruptive elements during the Temer presidency, which seriously affected its popularity.

\subsection{Colombia}

The Colombian case probably illustrates the agenda-setting effects deep structural problems might have on the political agenda. Contrary to Brazil, the use of violence in politics has characterized the country since independence. There were eight civil wars during the 19th century and the use of violence has characterized the relationship between the Liberal and Conservative parties founded in 1840. Violence consolidated as the normal way to handle politics also in the 20th century as the period known as "La Violencia" during which the two main parties entered a bloody war lasting from 1946 to 1960, or the emergence of new forms of violence from the 70's, illustrate (Kline, 2018). Marxist guerrilla groups followed by "self-defense" or "paramilitary" groups and later drug dealers led the country to a complex situation. In the nineties, Colombia was considered a failed state because of endemic crime and violence, and nation-wide terrorism that resulted in the displacement of the rural population and, due to generalized kidnapping, emigration abroad by professionals and the upper classes (Bruneau \& Goetze, 2019, p. 3). For this reason, political violence and especially the activity of paramilitary and guerrilla groups have a leading position in the political and media agendas.

All Colombian presidents attempted to end violence, but it was first under President Álvaro Uribe, 2002-2010, and next President Juan Manuel Santos, 2010-2018, who had been Minister of Defense under President Uribe from 2006-2010, who forced the FARC (Revolutionary Armed Forces of Colombia) to the negotiating table and greatly reduced violence in the country. The peace negotiations conducted by Santos to subscribe a treaty to lay down arms with the FARC formally began in 2012 . Even though the Colombia people rejected the treaty when 50.22 voted against it in a plebiscite in October 2016, the treaty was finally approved, following many changes, by the Colombian Senate 
in November 2016. Santos won the Nobel Peace Prize in 2016 for successful negotiations with the FARC. The successor of President Santos, Iván Duque, elected in 2018, faces many challenges. Progress on the implementation of peace accord has been weak and drug trafficking reached new records in 2017, when coca crops were estimated to extend to 209,000 hectares, with 921 metric tons of cocaine production annually (in 1999 there were 136,000 hectares of coca producing around 500 metric tons of cocaine when the U.S. Congress deemed it enough of an emergency to implement Plan Colombia in 1999) (Spencer, 2019, p. 83).

The political effect of violence in Colombia was so huge that paramilitary groups, guerrillas and criminal bands constrained for decades the role of civil society organizations and human rights groups. This explains, for example, why women groups have not been as organized as in other Latin American countries. Only indigenous groups managed to realize some of their political claims. Even though from the 70's Indian population mobilized politically in almost all Latin American countries, only in Colombia indigenous population has achieved politico-territorial autonomy when the 1991 constitution elevated indigenous reservations to the status of municipal governments (Kline \& Wade, 2018). At present, while violence and criminal bands are still a big problem in the country, the approval of the peace treaty provided the opportunity for new groups to promote the entry of new issues into the political agenda, like rights of women, gay people or political corruption (Kline, 2018, p. 190). For the first time in Colombia the voices of trade union movements, peasants, women, indigenous groups and environmentalist find expression overcoming old corporatist practices largely associated with the church, the armed forces, the landed and business elites (North \& Clarck, 2018). A key comparative question to explore is why this myriad of civil society organizations have different capacity to mobilize and influence the political agenda in different Latin American countries.

\subsection{Ecuador}

Finally, in Ecuador, major political and economic changes has occurred, mainly in a predominantly nonviolent way at the political level. The XIX century was characterized by violent conflicts between the conservative party, which represented landed oligarchs allied with the catholic church, and the liberal party, that represented coastal elites interested in commerce and secularization (Collins, 2018, p. 301). In 1925, the military took power from the Liberals but they identified themselves with reform not becoming an oppressive force, the 1972-1976 military government implemented a nationalist revolution aimed at modernization and retreated from power peacefully in a negotiated transition in 1979. The lack of systemic violence allowed leading actors from civil society having more freedom to organize and influence the political agenda, like the successful women's movement achievements illustrates. Ecuador was the first Latin American country to grant the right to vote to women's in 1929 and since then political advocacy has resulted in new achievements like the country adopting gender quotas for legislative elections in 1998 (Piatti-Crocker, 2019). Ecuador, allows for the exploration of agenda dynamics in a country where struggles for citizenship rights and political inclusion by indigenous people and afro-educadorians have produced important success in a country where racism has deep roots (Collins, 2018). 
Like in Brazil, the arrival of Correa into power in 2006 led to the implementation of a reformist agenda in line with the "new $21^{\text {st }}$-century socialism" turning back previous neo-liberal policies. Correa reached presidency in in a context where Ecuadorians were fed up with politicians, with citizens having low confidence in political institutions, high electoral volatility and a poor economic context. Correa won the presidential elections with a strong discourse against partitocracy fueling peoples anti party system feelings which led him to be considered a populist (García-Bryce, 2019). The agenda of Correa was characterized by the so called "Citizen's Revolution", a political project materialized in the 2008 Constitutional reform. A central concept in this political project was the buen vivir ("to live well") that emphasizes the importance of "living in harmony and balance with nature and other human beings, rejecting consumerism and individualism in favor of sustainability and community" (Collins, 2018, p. 307). In 2008, Ecuador was the first state ever to enshrine rights for nature in its Constitution (Eisenstadt \& West, 2019). Even though Correa promoted a political agenda that was at the beginning highly influenced by social moments, and particular indigenous communities, the president has clashed with social movements and distance himself from left oriented groups, promoting for example large scale mining which environmental associations strongly opposes. Important in terms of agenda-setting research is that Correa signed one of the most restrictive media laws in Latin America. In spite of this, during the Correa presidency the quality of democracy significantly improved, the levels of poverty were reduced and citizens" trust in institutions reached unprecedented levels. Lenín Moreno, the current president of Ecuador, who served as Correa's vice president from 2007 to 2013, defeated Guillermo Lasso, the opposition candidate, in 2017. Moreno seems to have recognized the contradictions of Correa Presidency and in working to take decisions in favor of indigenous rights and the environment (Eisenstadt \& West, 2019).

Finally, it is worth mentioning that Latin America and the Caribbean is the second most disaster-prone region in the world, with 152 million people affected by 1,205 disasters for the period 2000-20193. The analysis of how countries in the region react to these disasters is interesting given that their agenda setting effects are well documented among agenda-setting scholars (Jones \& Baumgartner, 2005; Kingdon, 1984). In 2016 Ecuador suffered one of the most serious earthquakes in recent history that led to the declaration of the state of emergency, but other examples can be found in the region, among the most recent and salient are the 2019 forest fires in the Amazon region. These resulted not only in intense political debates within the affected regions, Brazil among other countries, but also in mobilization and protest around the world as part of the increasing environmental awareness that is taking place among the public in many countries.

${ }^{3}$ According to the United nations Office for the Coordination of Humanitarian Affairs. 


\section{CONCLUSION}

Data from the Comparative Agendas allows for an unprecedented level of comparison of policies and policy-making within and between projects. While some of the data discussed in this paper are still being developed, the goal of this data, like all CAP data is its open and free use from researchers, students, practitioners, and others. Just as important as this newly introduced data is the existing and still growing data from beyond Latin America that makes for a truly global database of policy attention. This work is only possible due to the dedication of team members, PIs, the goodwill of the community at large, and a working Master Codebook. While many researchers will not call on the details of how the master codebook was created often, transparency in how it was created, how it works, and as a result its limitations hopefully gives researchers greater faith in the data.

The CAP data allow researchers, policymakers and students to assess trends in policy-making activities over time and among nations, overcoming the costs of obtaining comparable data usually associated with comparative research. The enlargement of the CAP community to Latin America will allow rich comparisons between countries, exploring questions that are of interest to Latin American studies. However, the potential to enlarge the CAP project to Latin America goes beyond the region. Having large comparable datasets will allow for the investigation of similarities and differences in agenda dynamics in Latin American and other regions in the world, addressing questions such as the impact of different institutional designs in policy outcomes, how the different configuration of the relationship between citizens, and the state affect policy priorities. For instance, do Latin American countries also have core issues (economy, defense, international relations, and government operations) that tend to dominate agendas (Jennings et al., 2011), or do fundamental concerns like political violence alter that core? How do special cultural and economic ties between Latin America and Spain (Chaqués-Bonafont, Palau, \& Baumgartner, 2015) manifest in terms of agenda convergence? Just as important as regional traits are the challenge that global threats such as climate change, or political phenomena like populism, represent for liberal democracies, questions where a world view beyond the global north and west is essential.

In recent years, the reinforcement of populism in Latin America, but also the United States and Europe exemplifies the crisis of political representation and particularly, the incapacity of traditional institutions and political leaders to integrate and represent citizens' will (Kats \& Mair, 1995; Laclau, 2005). Market globalization and the triumph of liberalism induced political convergence, uprooting parties from their social basis, promoting the development of political castes against which populist parties revealed politicizing grievances related to economic inequalities (on the left) and the dilution of ethno-nationalist identities (on the right) (Roberts, 2019). Populist parties have succeeded in mobilizing citizens that occupy a marginal position in the globalized economy or that feel their national community threated by multicultural societies. This has occurred in Western Europe, where party systems were historically effectively grounded in class cleavages but also in United States and Latin America with weaker parties as agents of mobilization. The growth of left populism in Latin America, for example in Venezuela, Ecuador, or Bolivia, and also in Southern European countries, especially in the aftermath of the financial crisis initiated in 2008, promise voters social protection from market liberalism and remedies 
RAP | The comparative agendas project in Latin America: data and coding

for the consequences of structural adjustment policies (Della Porta, Fernández, Kouki, \& Mosca, 2017; Kriesi \& Pappas, 2015). Right populism, such as that of Marie Le Pen in France, Donald Trump in the United States or Bolsonaro in Brazil, grew in parallel politicizing cultural aspects more than socio-economic aspects. They are oriented to protect their national communities from immigrants and economic globalization, which are perceived as a threat (Wodak, KhosraviNik, $\&$ Mral, 2013). The enlargement of the CAP project will allows for research into the extent that the agenda of populist leaders converge cross-nationally, a key question of interest in comparative research. 


\section{REFERENCES}

Adler, E. Scott., \& Wilkerson, John. D. (2013). Congress and the politics of problem solving. Cambridge, UK: Cambridge University Press.

Annesley, C., Engeli, I., \& Gains, F. (2015). The profile of gender equality issue attention in Western Europe. European Journal of Political Research, 54(3), 525-542.

Baumgartner, F. R., Brouard, S., Green-Pedersen, S., Jones, B. D., \& Walgrave, S. (2011). The Dynamics of Policy Change in Comparative Perspective. Comparative Political Studies, 44(8), 947-972.

Bevan, S., Baumgartner, F., Johnson, E., \& McCarthy, J. (2013). Understanding Selection Bias, Time-Lags and Measurement Bias in Secondary Data Sources: Putting the Encyclopedia of Associations Database in Broader Context. Social Science Research, 42(6), 1750-1764.

Bevan, S., \& Jennings, W. (2014). Representation, Agendas and Institutions. European Journal of Political Research, 53(1), 37-56.

Boydstun, A. E. (2013). Making the News: Politics, the Media, and Agenda Setting. Chicago, IL: University of Chicago Press.

Bruneau, T. C., \& Goetze, R. B., Jr. (2019). From Tragedy to Success in Colombia: The Centrality of Effectiveness in Civil-Military Relations. Washington, DC: William J. Perry Center for Hemispheric Defense Studies. Retrieved from http://hdl.handle. net/10945/62500

Chaqués-Bonafont, L., Palau, A. M., \& Baumgartner, F. R. (2015). Agenda dynamics in Spain. New York, NY: Springer.

Collins, J. N. (2018). Ecuador: change and Continuity after ten years of nw left revolution. In H. F. Kline, C. J. Wade, \& H. J. Wiarda. (Eds.), Latin American Politics and Development. London, UK: Routledge.

Crandall, B. H. (2018). Brazil: The Politics of Elite Rule. In H. F. Kline, C. J. Wade, \& H. J. Wiarda. (Eds.), Latin American Politics and Development. London, UK: Routledge.

Della Porta, D., Fernández, J., Kouki, H., \& Mosca, L. (2017). Movement parties against austerity. London, UK: John Wiley \& Sons.
Dowding, K., Hindmoor, A., \& Martin, A. (2016). The Comparative Policy Agendas Project: Theory, Measurement and Findings. Journal of Public Policy, 36(1), 3-25.

Eisenstadt, T. A., \& West, K. J. (2019). Who Speaks for Nature? Indigenous Movements, Public Opinion, and the Petro-state in Ecuador. Oxford, UK: Oxford University Press.

Fogel, B. (2019). Brazil: Corruption as a Mode of Rule: Tracing the roots of corruption in Brazil from Vargas to Bolsonaro reveals a political strategy that has long been woven into the fabric of Brazilian politics. NACLA Report on the Americas, 51(2), 153-158.

García-Bryce, I. (2019). Populism across the Andes during the 20th and Early 21st Centuries. Oxford: UK: Oxford Research Encyclopedia of Latin American History.

Gonçalves, F., \& Niedhardt, A. C. (2019). Agenda governamental brasileira: uma análise da capacidade e diversidade nas prioridades em políticas públicas no período de 2003 a 2014, Cadernos Gestão Pública e Cidadania, 24(78), 1-22.

Green-Pedersen, C., \& Wilkerson, J. (2006). How agenda-setting attributes shape politics: basic dilemmas, problem attention and health politics developments in Denmark and the US. Journal of European Public Policy, 13(7), 1039-1052.

Guiraudon, V. (2000). European Integration and Migration Policy: Vertical Policy Making as Venue Shopping. Journal of Common Market Studies, 38(2), 251-271.

Jennings, W., Bevan, S., Timmermans, A., Breeman, G., Brouard, S., Chaques, L. ... Mortensen, P. B. (2011). Effects of the Core Functions of Government on the Diversity of Executive Agendas. Comparative Political Studies, 44(8), 1001-1030.

Jones, B. D., \& Baumgartner, F. R. (2005). The politics of attention: How government prioritizes problems. Chicago, IL: University of Chicago Press.

Jones, B. D., Baumgartner, F. R., Breunig, C., Wlezien, C., Soroka, S., Foucault, M. ... Walgrave, S. (2009). A general empirical law of public budgets: A comparative analysis. American Journal of Political Science, 53(4), 855-873. 
Katz, R. S., \& Mair, P. (1995). Changing models of party organization and party democracy: the emergence of the cartel party. Party politics, 1(1), 5-28.

Kline, H. F. (2018). Colombia: Is Guerrila violence near its end? In H. F. Kline, C. J. Wade, \& H. J. Wiarda. (Eds.), Latin American Politics and Development. London, UK: Routledge.

Kline, H. F., Wade, C. J., Wiarda, H. J. (2018). Latin American Politics and Development. London, UK: Routledge.

Kriesi, H., \& Pappas, T. S. (Eds.). (2015). European populism in the shadow of the great recession (pp. 1-22). Colchester, UK: Ecpr Press.

Laclau, E. (2005). On populist reason. New York, NY: Verso.
North, L. L., \& Clark, T. D. (2018). Dominant Elites in Latin America: From Neo-Liberalism to the 'Pink Tide. Cham, Switzerland: Palgrave Macmillan.

Piatti-Crocker, A. (2019). The Diffusion of Gender Policy in Latin America: From Quotas to Parity. Journal of International Women's Studies, 20(6), 44-59.

Roberts, K. M. (2019). Crises of Representation and Populist Challenges to Liberal Democracy. Chinese Political Science Review, 4(2), 188-199.

Spencer, D. E. (2019). Security Challenges of the New Colombian Administration. PRISM, 8(1), 82-95.

Wodak, R., KhosraviNik, M., \& Mral, B. (Eds.). (2013). Right-wing populism in Europe: Politics and discourse. London, UK: A\&C Black.

\section{Shaun Bevan}

https://orcid.org/0000-0001-7717-7822

Ph.D. in Political Science; Senior Lecturer at the Department of Politics and International Relations of the University of Edinburgh. E-mail: shaun.bevan@gmail.com

\section{Anna M. Palau}

https://orcid.org/0000-0002-3473-1114

Ph.D. in Political Science; Serra Húnter Associate Professor at the Department of Political Science, Constitutional Law and and Philosophy of Law of the University of Barcelona. E-mail: apalau@ub.edu 